\title{
CONSUMER ETHNOCENTRISM AND SOCIAL IDENTITY: THEORETICAL BACKGROUNDS AND EMPIRICAL STUDIES OVERVIEW
}

\section{POTROŠAČKI ETNOCENTRIZAM I SOCIJALNI IDENTITET: TEORIJSKA POZADINA I PRIKAZ EMPIRIJSKIH STUDIJA}

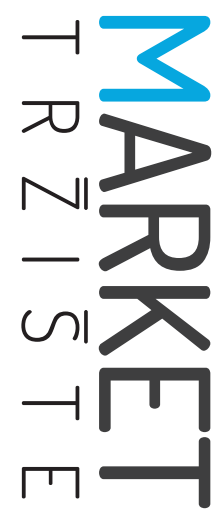

Market-Tržište

Vol. 32, Special Issue, 2020, pp. 131-146

UDK 658.89:658.62

D0l http://dx.doi.org/10.22598/mt/2020.32.spec-issue.131

Review

\section{Marija Čutura}

University of Mostar, Faculty of Economics, Matice hrvatske, bb, 8800 Mostar, BOSNIA AND HERZEGOVINA, e-mail: marija.cutura@ef.sum.ba

\begin{abstract}
Purpose - The purpose of this paper is to provide insight into the interplay between consumer ethnocentrism and social identity as concepts with significant relevance for different consumer responses in globalized environment.
\end{abstract}

Design/Methodology/Approach - The paper contains analysis of theoretical foundations, based on social identity theory, as well as conceptual content analysis of selected studies that deal with both the observed concepts.

Findings and implications - This paper contributes to deeper insights into the interplay between consumer ethnocentrism and identity, and provides a good foundation for explaining and predicting different consumers' responses in the globalized environment. From the perspective of social identity theory, ethnocentrism is considered to be an important factor in maintaining social identity and preserving it in the changing environment. This proposition is confirmed by empirical studies that show a positive relation between identity and consumer ethnocentrism. On the other hand, some empirical studies reveal somewhat mixed results which indicate that consumer ethnocentrism does not always correspond with the strength of identity. Also, studies that deal with consumer ethnocentrism and identity in

\section{Sažetak}

Svrha - Svrha je ovoga rada ponuditi uvid u interakciju između potrošačkog etnocentrizma i socijalnog identiteta kao koncepata od velikog značaja za različite reakcije potrošača u globaliziranom okružju.

Metodološki pristup - Rad sadrži analizu teorijskih polazišta koncepata, zasnovanih na teoriji socijalnog identiteta, kao i konceptualnu analizu sadržaja odabranih studija koje se bave potrošačkim etnocentrizmom i identitetom.

Rezultati i implikacije - Rad doprinosi dubljem uvidu $\mathrm{u}$ interakciju potrošačkog etnocentrizma $\mathrm{i}$ identiteta pružajući dobru osnovu za pojašnjenje i predviđanje različitih potrošačkih reakcija u globaliziranom okruženju. Iz perspektive teorije socijalnog identiteta, etnocentrizam predstavlja važan čimbenik u održavanju i očuvanju identiteta u promjenjivom okruženju. Navedena teorijska propozicija potvrđena je empirijskim studijama koje upućuju na pozitivan odnos između potrošačkog etnocentrizma i identiteta. S druge strane, određene studije pokazuju nešto drugačije rezultate $u$ kojima razina etnocentrizma i snaga identiteta nisu u potpunosti usklađene. Studije koje se bave potrošačkim etnocentrizmom i identitetom, u kontekstu globalnih promjena i akulturacijskog procesa, upućuju na kompleksnost relacijske matrice između ovih dvaju koncepata. 
the context of global changes and acculturation processes suggest that the relational matrix of those concepts can be far more complex.

Limitations - The observed theoretical backgrounds mostly consider classical propositions of the social identity theory and focus on specific forms of social identity.

Originality - This paper represents a synthesis of the dynamic perspective of social identity theory with conceptual analysis of consumer studies that deal with consumer ethnocentrism and identity.

Keywords - social identity theory, social identity, intergroup relation, ethnocentrism, consumer ethnocentrism
Ograničenja - Rad se, u većoj mjeri, zasniva na propozicijama klasične teorije socijalnog identiteta fokusirajući se na specifične oblike socijalnog identiteta.

Doprinos - Rad predstavlja sintezu dinamičke perspektive teorije socijalnog identiteta s konceptualnom analizom studija koje se bave potrošačkim etnocentrizmom i identitetom.

Ključne riječi - teorija socijalnog identiteta, socijalni identitet, međugrupni odnosi, etnocentrizam, potrošački etnocentrizam 


\section{INTRODUCTION}

Interest in identity in consumer studies is not a recent trend. In the last two decades, a significant number of studies have focused on theoretical and empirical confirmation of specific interaction between identity and consumer ethnocentrism. From the perspective of classical social identity theory, founded by Tajfel in the late 1960s and developed later with his associate Turner, ethnocentrism is seen as a result of ingroup identification. In terms of social identity theory, ingroup refers to a group of people who share some common characteristics, as well as social experience (Brewer, 2001). In a described context, ethnocentrism is strongly linked to group affiliation, as well as to the processes of establishing positive social identity. This view on ethnocentrism is in line with the most influential definition of consumer ethnocentrism proposed by Shimp and Sharma (1987). In Shimp and Sharma's seminal paper, consumer ethnocentrism was defined as a concept which "gives the individual a sense of identity, feelings of belongingness, and, most importantly, an understanding of what purchase behaviour is acceptable or unacceptable to the ingroup" (1987, p. 280). In today's world, people's social experience is shaped by different changes which result from globalization processes. The environment marked by social change often corresponds to insecure social identity, which initiates a variety of people's reactions.

The purpose of this paper is to provide an insight into the nature of the interplay between identity and consumer ethnocentrism through deeper theoretical insights and overview of consumer studies that deal with both concepts. The main goal of the analysis is to emphasize the importance of the interplay between ethnocentrism and identity in understanding and predicting different consumers' responses in a rapidly changing environment. The term consumers' response is used as a common term for a wide range of consumers' reactions that occur as consequences of observed concepts. Considering the fact that social identity is a complex phenomenon rooted in different disciplines, in this paper theoretical approach to identity is mostly based on a classical social identity theory. Theoretical identity analysis contains the most important aspects of classical social identity theory, intergroup relations and social categorization, linked to the conceptualization of consumers' ethnocentrism proposed by Shimp and Sharma (1987). Although ethnocentric attachment to the ingroup can be observed in different types of groups, the concept of ethnocentrism is originally developed to refer to an allegiance to national or ethnic group identities (Brewer, 2007). Therefore, this analysis focuses on specific forms of group-based social identities: national and ethnic identity. Conceptual content analysis, as a tool used to determine the presence of certain concepts within the studies and their relations, has been used for the analysis of empirical studies. The analysis of the content of empirical studies contains consumer studies that deal with the same conceptualization and operationalization of consumer ethnocentrism, as well as with the same forms of social identity operationalized in a similar manner. Discussion and conclusion are presented at the end of the paper, along with the most important contributions and limitations of the given analysis.

\section{THEORETICAL BACKGROUNDS OF THE INTERPLAY BETWEEN SOCIAL IDENTITY AND ETHNOCENTRISM}

Social identity theory reflects the convergence of two traditions in the study of intergroup relations - social categorization and social comparison (Brewer, 2007). Intergroup relations can be defined as the way people see themselves as members of one group or category in comparison with other groups and categories (Stets \& Burke, 2000). Starting in the mid- 
1960s, Tajfel, later in collaboration with Turner, integrated ethnocentrism within the concept of social identity (Hogg, Abrams, Otten \& Hinkle, 2004). As a typical example of various psychological processes which follow from group membership, Tajfel and Turner pay special attention to the concept of ethnocentrism. This part of the paper focuses on basic theoretical backgrounds of the interplay between ethnocentrism and identity through the processes of intergroup relations and social categorization as important aspects of overall social identity theory. These two aspects of the social identity theory are fundamental theoretical links to conceptualization of consumer ethnocentrism as well as towards deeper insights in the interplay between social identity and consumer ethnocentrism.

\subsection{Social identity, intergroup relations and social categorization}

The main thesis of the classical social identity theory is that people feel a desire to build positive identity of themselves, which consequently leads to their identification with various groups (Tajfel, 1982). Looking from the social perspective, self-definition can be established in the form of social identity (Tajfel, 1974). "Social identity is defined as a part of the individual's self-concept derived from the sense of membership to a social group (or groups) along with the emotional significance attached to that membership" (Tajfel \& Turner, 1979, p. 251). Social identity can also be defined as awareness of belonging to a group or some other social category (Hogg \& Abrams, 1988). A social group represents people who have the same social identity, which means that they identify themselves in the same way, and relate towards outgroups in the same way (Hogg et al., 2004). Social categorization and comparison are two important processes that underline social identity formation (Stets \& Burke, 2000).

To enhance their self-esteem, individuals and groups strive for positive social comparisons with a purpose of achieving positive social identity (Tajfel, 1982, p. 24). Social group membership contributes to positive social identity, preserving positively established distinctiveness from other groups (Tajfel, 1974). Social categorization represents a key precondition for social comparison and intergroup relations in general. "The processes of categorization a human uses to systematize and simplify social environment, therefore social categorization can be understood as the ordering of social environment in terms of social categories, in a manner which is meaningful to the subject" (Tajfel, 1974, p. 69). Social categories in which individuals place themselves exist only in relation to other contrasting categories (Hogg \& Abrams, 1988). This means that social categorization serves for the systematization of the social environment by defining individual place in society and providing opportunities for many forms of social actions (Tajfel \& Turner, 1979).

\subsection{Social identity and ethnocentrism}

There is a widely accepted consensus that American sociologist Sumner was the first to coin the term ethnocentrism. Sumner (1906, p. 13) defined ethnocentrism as "the view of things in which one's group is the center of everything, and others are scaled and rated with a reference to it". Sumner's view on ethnocentrism contains several principles: the social categorization, ingroup positivity, intergroup comparison and the outgroup hostility principle (Brewer, 2007, p. 729). On the other hand, Tajfel (1982) argues that most of the studies on ethnocentrism have not found a clear evidence that ingroup attachment is simultaneously related to outgroup negativism. Ethnocentrism, as a result of a strong identification with the ingroup, can in some circumstances lead to negative feelings towards the outgroup. Specific circumstances that can trigger negative feelings towards the outgroup can be a social situation which results in threats to the established social identity. In that context, Tajfel (1982, p. 32) suggests that 
ethnocentrism should be observed in considerations with psychological aspects of social stability and social change. This approach takes into account the reality of social environment as well as the reflection of intergroup relations in social behaviour, which is "mediated by the socially shared system of beliefs" (Tajfel \& Turner, 1979 , p. 36). The situation of social change can correspond with a negative or threatened social identity and a variety of reactions that can be outlined. Tajfel (1974) argues that a completely secure social identity is not empirically possible. The author states that every social structure is continuously challenged from the groups which tend to preserve (superior group) or to change (inferior group) the established social structure. Naturally, this assumption relies on categorization criteria when one group is considered superior and another inferior, which is in line with the basic definition of ethnocentrism proposed by Sumner (1906). Brewer (2007, p. 729) states that theoretical and empirical evidences on intergroup relations provide several conclusions. Firstly, ingroup attachment and positivity are primarily and in most cases independent of outgroups. Secondly, security motives (belonging and distinctiveness) underlie universal ingroup favouritism. Finally, attitudes towards outgroups vary as a function of intergroup relations and associated threats to belonging and distinctiveness. In the social context, different forms of threats may affect intergroup relations and lead to outgroup negativity and hostility. Those threats, among others, can be expressed through real threats to the ingroup material wellbeing (e.g. foreign competition), or through symbolic threats (e.g. outgroup values and standards) to the ingroup worldview (Stephan \& Stephan, 2000). From the perspective of social identity, ethnocentrism is regarded as a result of attachment to the ingroup which initiates different forms of ingroup reactions, such as ingroup favouritism, cooperation and solidarity, especially in the face of shared social experience of common threats and challenges.

\section{CONSUMER} ETHNOCENTRISM IN THE FRAMEWORK OF SOCIAL IDENTITY THEORY

In this part of the paper, the theoretical analysis deals with the conceptualization of consumer ethnocentrism by establishing links between social identity theory and the development of the consumer ethnocentrism concept. This part of analysis also shows theoretical relations between social identity and consumer ethnocentrism, including the relation in the changing environment caused by the globalization process.

\subsection{Social categorization, ingroup favouritism and consumer ethnocentrism}

The studies on the country of origin started in the late 1960s and initially relied on a wide range of consumers' stereotypes and other reactions towards countries and their products (Verlegh, 1999). The implications of the social identity theory on the studies on the country of origin are linked to the process of social categorization, which is also connected to the conceptualization of consumer ethnocentrism developed later on. In that context, social categorization relies on the assumption that people distinguish their social categories even in the situation of purchase (Lanz \& Loeb, 1996; Verlegh, 1999). The specific consequence of social categorization is an accentuation of the perceived differences between ingroups and outgroups that affect attitudes, beliefs, values and other properties correlated with social categorization (Stets \& Burke, 2000). The perceived differences between social categories rely on a set of universal stereotypes which characterize ingroup/outgroup differences (Brewer, 2007). In the case of purchase situation, social categorization provides a classification of related social objects in ingroup categories (i.e. domestic products, home country origin) and in outgroup categories (i.e. imported products and foreign country of origin). 


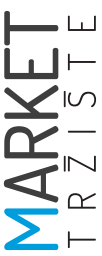

As shown in the previous part of the theoretical analysis, ethnocentrism is a result of deep attachment to ingroup and is strongly linked to ingroup favouritism. Although the studies on the tradition of country of origin, among others, deal with consumers' positive preferences towards products of domestic origin, according to Pecotich and Rosenthal (2001), a strong theoretical and empirical explanation of consumer ethnocentrism was not offered before Shimp and Sharma's (1987) seminal paper. As noted above, Shimp and Sharma (1987) state that consumer ethnocentrism gives the individual a sense of identity and the feeling of belonging, and provide an understanding of what purchasing behaviour is acceptable or unacceptable to the ingroup. For ethnocentric consumers, domestic products (i.e. ingroup) are objects of pride and attachment in comparison with imported products (i.e. outgroup), which are objects of contempt (Shimp \& Sharma, 1987). This explanation clearly suggests that ingroup perspective is the basic starting point for the conceptualization of consumer ethnocentrism. Moreover, from the perspective of social identity theory, the most important characteristics of ethnocentric attachment to the ingroup are loyalty and preferences (Brewer, 2007). Both these characteristics follow from the fact that ingroup serves as a bounded community of cooperation and trust (Brewer, 1999). In line with this proposition, Sharma, Shimp and Shin (1995, p. 26) stressed that consumer ethnocentrism enables the preservation of ingroup interests fostering group conformity, cooperation, loyalty and solidarity. Group interests come into focus especially in the circumstances of a perceived threat to the ingroup, and in the case of consumer ethnocentrism, foreign competition is seen as a certain threat. "For many individuals, the quality of life and economic livelihood are "threatened" by foreign competition (Shimp \& Sharma, 1987, p. 286). Additionally, authors explained that ethnocentric consumers consider purchasing imported products as wrong and unpatriotic because it hurts the domestic economy. Some later studies on consumer ethno- centrism have also confirmed that this concept entails affective dimensions, such as belonging and the sense of identity, normative elements with respect to what individual should do from the point of view of ingroup interests, as well as cognitive processes that evaluate purchase behaviour with respect to domestic economy (Vida \& Reardon, 2008).

\subsection{Consumer ethnocentrism and social identity}

The traditional approach to ethnocentrism as an ingroup favouritism which generates different ingroup responses should be extended with a better understanding of the interplay between social identity and ethnocentrism. This analysis focuses on a group-based identity, which is well captured by the social identity theory based on social categorization and traditionally defined as social identity (Brewer, 2001). Group-based identities provide uniformity of perception that can be expressed through different cognitive, attitudinal and behavioural reactions of group members (Stets \& Burke, 2000). Verlegh (2007, p. 370) pointed out that consumer favouritism towards own country can be initiated by at least two different motives. The first motive is consumer ethnocentrism, which reflects consumer's desire to protect the domestic economy. The second motive is socio psychological in nature, and that is national identification. National identity, as a form of group-based identity, is build-up through the process of social categorization as well as through the process of comparison of one's own country as a territory of ingroup with other countries as outgroups. According to Verlegh (2007), national identification represents a need for establishing a positive national identity, as an important dimension of overall self-enchantment.

Consumers' identification with different social groups and with a particular nation, culture or ethnic group, along with bounded sentiments, may be reflected in different consumers' responses (Hershe, 1994). Despite the fact that ethnocentric attachment to the ingroup can be 
observed in different types of groups, the concept of ethnocentrism is originally developed to refer to allegiance to national or ethnic group identities (Brewer, 2007). According to Phinney, Horenczyk, Liebkind and Vedder (2001), national identity involves attitudes and the feeling of belonging toward a larger social group, such as country or nation. On the other hand, ethnic identity is mostly seen as an important element of the overall national identity. Ethnic identity refers to an individual's sense of self in terms of membership to a particular ethnicity, which implies beliefs about common ancestry and sharing one or more of the following elements: religion, culture, language, kinship and place of origin (Phinney, 1990). The ingroup biases that accompany the awareness of national belonging may be considered as the driving force behind the phenomenon of consumer ethnocentrism (Verlegh, 1999). Within a social identity tradition, ethnocentrism is primarily seen as a preference for the ingroup over outgroup, referring to positive ingroup biases and arguing against equating those ingroup biases with outgroup negativity (Bizumic \& Duckitt, 2012). In line with the social identity theory, the studies on consumer ethnocentrism in most cases refer to ingroup favouritism, rather than to outgroup negativism. Consumer ethnocentrism has been confirmed as a stronger predictor of consumer preferences towards domestic products than towards imported alternatives (Balabanis \& Diamantopoulos, 2004).

\subsection{Consumer ethnocentrism and social identity in the changing environment}

Globalization is an objective process of structuring economy, societies, institutions and cultures and there is a certain systematic relation between globalization and identity forces (Castells, 1997). Globalization as a complex phenomenon causes social changes. From the perspective of social identity theory, a social change refers to a structural change related to groups in total. This perspective takes into con- sideration a realistic situation of social change that affects mutual relations, behaviour and attitudes of a large scale of social groups, particularly when the process of change becomes very rapid, as it is case with the globalization process (Tajfel \& Turner, 2004, p. 280). From the perspective of the social identity theory, ethnocentrism as a result of the attachment to ingroup is strongly linked to the processes of establishing a positive social identity. Understanding the ingroup as a set of people who share common characteristics or social experience (Brewer, 2001, p. 117) is a very important perspective that enables better understanding of relations between ethnocentrism and identity. Shared social experience includes the same social interpretation of common threats and challenges. It is reasonable to expect that consumer ethnocentrism will increase if there is a perceived threat to the ingroup, and foreign competition can be perceived as a threat to the economic wellbeing of the nation (Lantz \& Loeb, 1996, p. 374). In contemporary societies, globalized markets are the space of multidimensional exchange. One of the most visible dimension of that exchange is the exchange of products and services. The other, more abstract dimension of global exchange, encompasses ideas, symbolic meanings and values as important elements of another culture. Social changes which result from the contact with different cultures are broadly defined as acculturation process. Acculturation process implies a wide range of behaviours, attitudes and values that change in contacts between cultures (Phinney et al., 2001, p. 495). Although the concept of acculturation is not in the scope of this paper, it is important to note that recent studies that deal with the concept of consumer acculturation in the global culture have included consumer ethnocentrism and identity in their research framework. Therefore, the following analysis contains studies that deal with a specific concept of acculturation, but only in the aspects important for the interplay between identity and ethnocentrism.

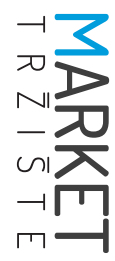




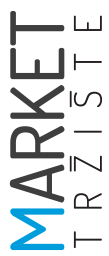

\section{THE ANALYSIS OF THE STUDIES OF CONSUMER ETHNOCENTRISM AND SOCIAL IDENTITY}

This part of the paper deals with a conceptual content analysis of empirical studies that observe an interplay between consumer ethnocentrism and social identity. The analysed studies were published in indexed journals and are available in relevant databases, such as Web of Science Core Collection, Scopus and ABI/Inform. The studies were firstly identified through key words: consumer ethnocentrism, social identity and national identity. After identifying studies that entail these key concepts, methodological approaches to the observed key concepts were analysed as the final selection criteria. As it was mentioned before, the main selection criteria for study observation was the use of the same conceptualization of consumer ethnocentrism, along with an established consumer ethnocentrism measurement (CETSCALE - CET) proposed by Shimp and Sharma (1987). All selected studies also deal with the same conceptualization and with the same or very similar operationalization of social identity. The observed studies were based on the questionnaire survey methods and sampling adult population (18+ years old).

The analysis of empirical studies follows three broadly established levels of interplay between consumer ethnocentrism and identity in correspondence with three categories of the observed studies. The first level of analysis entails a category of studies that found variations in consumer ethnocentrism based on national, cross-national or sub-national consumer characteristics. The second level of analysis encompasses studies where identity has been intentionally operationalized and measured in interaction with consumer ethnocentrism. The third level of the analysis entails the category that deals with an interplay between consumer ethnocentrism and identity in the context of consumers' responses to the global acculturation processes.

\subsection{National, cross-national and sub-national perspectives of consumer ethnocentrism}

An overview of consumer ethnocentrism studies that have confirmed variations in consumer ethnocentrism levels based on national, cross-national and sub-national characteristics is shown Table 1.

In the preliminary study of consumer ethnocentrism, Shimp and Sharma (1987) found different levels of consumer ethnocentrism in different regional areas of the United States (Detroit, Denver, Los Angeles and Carolinas), suggesting that consumer ethnocentrism should also be tested with respect to ethnic characteristics of consumers. In the study of Turkish consumers, Kaynak and Kara (2002) found differences in the level of consumer ethnocentrism among and within four urban areas. The authors concluded that the observed differences were a result of different degrees of strength in identifying with important aspects of ethnic belonging. Cleveland and others (2009) conducted research on several consumer concepts in urban areas of eight countries (Canada, Mexico, Chile, Sweden, Greece, Hungary, India and South Korea). The authors reported that consumer ethnocentrism had greatest variations within and between the countries. Herche and Balasubramamaian (1994) used ethnic quota sampling of different areas in the US and confirmed that consumer ethnocentrism significantly varies among six groups with different ethnic origin (Afro-Americans, Hispano-Americans, Chinese, Japanese, Italians and Koreans). Similar results were found in the study of Australian consumers, where Greek-Australians showed a lower level of consumer ethnocentrism in comparison with Australians (Zarkada-Frazer \& Frazer, 2002). The level of consumer ethnocentrism also differs among three dominant ethnic groups, namely Bosniaks, Serbs and Croats that live in Bosnia and Herzegovina (Cutura, 2012). 
TABLE 1: Consumer ethnocentrism variations based on national, cross-national or sub-national characteristics

\begin{tabular}{|c|c|c|}
\hline $\begin{array}{l}\text { Shimp \& Sharma } \\
\text { (1987) }\end{array}$ & Study of US consumers & $\begin{array}{l}\text { Different levels of consumer ethnocentrism } \\
\text { (CET) found among consumers from four } \\
\text { different regional areas of the United States. }\end{array}$ \\
\hline $\begin{array}{l}\text { Cleveland, Laroche } \\
\text { \& Papadopoulos } \\
\text { (2009) }\end{array}$ & $\begin{array}{l}\text { Cross-cultural study of } \\
\text { eight countries with } \\
\text { different cultural and } \\
\text { economic characteristics }\end{array}$ & $\begin{array}{l}\text { Among other observed concepts, consumer } \\
\text { ethnocentrism (CET) had the greatest variations } \\
\text { across and within the countries. }\end{array}$ \\
\hline $\begin{array}{l}\text { Kaynak \& Kara } \\
\text { (2002) }\end{array}$ & $\begin{array}{l}\text { Study of Turkish } \\
\text { consumers }\end{array}$ & $\begin{array}{l}\text { The level of consumer ethnocentrism (CET) } \\
\text { varied across and within different urban areas } \\
\text { as a result of different degree of strength in } \\
\text { identifying with some aspects of ethnic identity. }\end{array}$ \\
\hline $\begin{array}{l}\text { Zarkada-Fraizer \& } \\
\text { Frazer (2002) }\end{array}$ & $\begin{array}{l}\text { Study of Australian } \\
\text { consumers }\end{array}$ & $\begin{array}{l}\text { Consumers who belong to different sub-groups } \\
\text { (Greek-Australians and Australians) differ in the } \\
\text { level of consumer ethnocentrism (CET). }\end{array}$ \\
\hline $\begin{array}{l}\text { Herche \& } \\
\text { Balasubramamaian } \\
\text { (1994) }\end{array}$ & $\begin{array}{l}\text { The study of six ethnic } \\
\text { groups from different } \\
\text { areas of the US }\end{array}$ & $\begin{array}{l}\text { Consumer ethnocentrism (CET) significantly } \\
\text { varied among six groups with different ethnic } \\
\text { origin (Afro-Americans, Hispano-Americans, } \\
\text { Chinese, Japanese, Italians and Koreans). }\end{array}$ \\
\hline Cutura (2012) & $\begin{array}{l}\text { Study of consumers in } \\
\text { Bosnia and Herzegovina }\end{array}$ & $\begin{array}{l}\text { In case of three ethnic groups (Bosniaks, Serbs } \\
\text { and Croats) ethnic belonging appeared as a } \\
\text { significant predictor of the level of consumer } \\
\text { ethnocentrism (CET). }\end{array}$ \\
\hline
\end{tabular}

Source: Author's overview

\subsection{Consumer ethnocentrism studies in the national identity framework}

"Ethnocentrism is included in the national identity framework as a way of accounting for the importance placed on maintaining culturally-cantered values and behaviours" (Keillor \& Hult, 1999, p. 69). The previous thesis was also confirmed by later empirical studies that established positive relations between national identity and consumer ethnocentrism, which can be seen from the overview of studies in Table 2 . As noted before, the analysed studies that deal with an interplay between ethnocentrism and identity have the same conceptualizations of consumer ethnocentrism and identity. Also, all observed studies have the same or very similar operationalization of identity that can be divided into two main lines. The first line of operationalization relies on the national identity scale (NATID) first proposed by Keillor, Hult, Erffemeyer and Babakus (1996), and later confirmed by many other studies in different cross-national and national environments. The second line of studies relied on national identity (NID) proposed by Cleveland and his associates (Cleveland \& Laroche, 2007; Cleveland, Laroche, \& Papadopoulos, 2011). In this operationalization, national identity (NID) is seen as a contextual one, therefore this analysis also takes into consideration several related operationalizations related to national Identity (NID) (i.e. national 
TABLE 2: Consumer ethnocentrism and national identity

\begin{tabular}{|c|c|c|}
\hline Keillor \& Hult (1999) & $\begin{array}{l}\text { Cross-national study of five } \\
\text { countries with different cultural } \\
\text { and economic characteristics }\end{array}$ & $\begin{array}{l}\text { Within national identity (NATID), as a } \\
\text { second-order construct, in relation } \\
\text { to consumer ethnocentrism (CET) } \\
\text { as a first order construct, significant } \\
\text { variations between and among } \\
\text { studied countries were observed. }\end{array}$ \\
\hline $\begin{array}{l}\text { Vida, Dmitrovic \& } \\
\text { Obadia (2008) }\end{array}$ & $\begin{array}{l}\text { Study of consumers in Bosnia } \\
\text { and Herzegovina }\end{array}$ & $\begin{array}{l}\text { National identity (NATID) is positively } \\
\text { related to consumer ethnocentrism } \\
\text { (CET). }\end{array}$ \\
\hline $\begin{array}{l}\text { Cleveland, Laroche \& } \\
\text { Papadopoulos (2011) }\end{array}$ & $\begin{array}{l}\text { Cross-national study of eight } \\
\text { countries with different cultural } \\
\text { and economic characteristics }\end{array}$ & $\begin{array}{l}\text { Ethnic identity (EID) is positively } \\
\text { related to consumer ethnocentrism } \\
\text { (CET) in both developed and less } \\
\text { developed countries. }\end{array}$ \\
\hline $\begin{array}{l}\text { El Banna, } \\
\text { Papadopoulos, Murphy, } \\
\text { Rod \& Rojas-Méndez } \\
\text { (2017) }\end{array}$ & Study of Canadian consumers & $\begin{array}{l}\text { Ethnic identity (one dimension of } \\
\text { EID) is related to a higher level of } \\
\text { consumer ethnocentrism (CET) in } \\
\text { case of both subsamples (Egyptian } \\
\text { Canadians and Canadians). }\end{array}$ \\
\hline He \& Wang (2015) & Study of Chinese consumers & $\begin{array}{l}\text { Identity (adopted NATID) has } \\
\text { significant influence on consumer } \\
\text { ethnocentrism (CET). }\end{array}$ \\
\hline $\begin{array}{l}\text { Zeugner-Roth, } \\
\text { Diamantopoulos \& } \\
\text { Zabkar (2015) }\end{array}$ & $\begin{array}{l}\text { Study of Austrian and Slovenian } \\
\text { consumers }\end{array}$ & $\begin{array}{l}\text { National identity (NATID) is positively } \\
\text { related to consumer ethnocentrism } \\
\text { (CET) in both countries. }\end{array}$ \\
\hline
\end{tabular}

Source: Author's overview

ethnic identity - NEID and ethnic identity - EID), depending on the context of research.

The results of studies outlined in Table 2 point to several conclusions. Most studies confirm that national and ethnic identity are positively related to consumer ethnocentrism. On the other hand, the study on national identity Keillor \& Hult (1999) reveals somewhat mixed results. The authors observed national identity as a second-order construct with five first-order factors. These first-order factors (national heritage, cultural homogeneity, belief system and consumer ethnocentrism) were seen as indicators rather than determinates of overall national identity. Keillor and Hult (1999) conducted a research in five countries (USA, Japan, Sweden, Hong Kong and Mexico). The results show that the relational matrix between national identity and the second-order factors, including consumer ethnocentrism, varies across the observed countries, suggesting that consumer ethnocentrism does not uniformly correspond to the strength of national identity. Cleveland and others (2011) have conducted research in urban areas of five countries (Mexico, Chile, India, Hungary, Canada, Sweden, Greece and South Korea). This study points to the conclusion that relations between ethnic identity and consumer ethnocentrism were significantly positive for both developed and less developed countries, but were not uniformly distributed with respect to the strength of ethnic identity. Although identity and consumer ethnocentrism were found to be positively related in the case of Canadians and Egyptian-Canadians, ethnic identity as an identification with 
a unique ethnic group affects different levels of consumer ethnocentrism (El Banna et al., 2017). When it comes to the moderating effect of national identity on domestic preferences, it was found to be positive in most observed studies, but in some cases national identity score was higher than the consumer ethnocentrism score (Zeugner-Roth et al., 2015).

\subsection{Ethnocentrism and identity in the context of consumer acculturation to the global culture}

The following analysis contains studies that deal with a specific concept of acculturation. The analysis is focused on the aspects important for the interplay between identity and ethnocentrism. According to Cleveland and Laroche
(2007, p. 252), "Acculturation to Global Consumer Culture (AGCC) considers how individuals acquire the knowledge, skills and behaviours that are characteristic of a nascent and deterritorialized global consumer culture". The concept has been operationalized as multidimensional and represents a set of constructs that are intended to directly measure consumers' dispositions toward global culture. This analysis focuses on the interplay between identity and ethnocentrism, in the context of previously described multidimensional construct of consumer acculturation to the global culture. An overview of the described studies is presented in Table 3.

Fan overview of the studies in Table 3 show that in the most cases consumer ethnocentrism and identity are positively related. This means that ethnocentrism affects consumers' intentions

TABLE 3: Ethnocentrism and identity in the context of studies that deal with consumer acculturation to global culture

\begin{tabular}{|l|l|l|}
\hline $\begin{array}{l}\text { Cleveland \& } \\
\text { Laroche (2007) }\end{array}$ & $\begin{array}{l}\text { Consumer study } \\
\text { in Canada }\end{array}$ & $\begin{array}{l}\text { Ethnic identity (EID) and consumer ethnocentrism (CET) } \\
\text { are positively related. } \\
\text { acculturation to global consumer culture (AGCC) and } \\
\text { consumer ethnocentrism (CET) are negatively related. }\end{array}$ \\
\hline $\begin{array}{l}\text { Cleveland, Laroche } \\
\text { T Takahashi (2015) }\end{array}$ & $\begin{array}{l}\text { Consumer study } \\
\text { in Japan }\end{array}$ & $\begin{array}{l}\text { Ethnic identity (EID) is negatively related to consumer } \\
\text { ethnocentrism (CET). } \\
\text { Consumer ethnocentrism (CET) and acculturation to } \\
\text { global consumer culture (AGCC) are negatively related. }\end{array}$ \\
\hline $\begin{array}{l}\text { Cleveland, Rojas- } \\
\text { \&endez, Laroche } \\
\text { (2016) }\end{array}$ & $\begin{array}{l}\text { Consumer study } \\
\text { in Chile and } \\
\text { Canada }\end{array}$ & $\begin{array}{l}\text { National identity (NID) and consumer ethnocentrism } \\
\text { CET are positively related. } \\
\text { Consumer ethnocentrism (CET) is positively related with } \\
\text { openness to global culture as a dimension of overall } \\
\text { acculturation to global consumer culture (AGCC). }\end{array}$ \\
\hline $\begin{array}{l}\text { Sobol, Cleveland \& } \\
\text { Laroche (2018) }\end{array}$ & $\begin{array}{l}\text { Longitudinal } \\
\text { study of Dutch } \\
\text { consumers }\end{array}$ & $\begin{array}{l}\text { National ethnic identity (NEID) and consumer } \\
\text { ethnocentrism (CET) are positively related. } \\
\text { Consumer ethnocentrism and acculturation to global } \\
\text { consumer culture (AGCC) are negatively related. }\end{array}$ \\
\hline $\begin{array}{l}\text { Gonzales-Fuentes } \\
\text { (2019) }\end{array}$ & $\begin{array}{l}\text { Consumer study } \\
\text { in Japan and USA }\end{array}$ & $\begin{array}{l}\text { In both countries, consumer acceptance of the } \\
\text { global acculturation processes depends on relational } \\
\text { matrix between ethnic identity (EID) and consumer } \\
\text { ethnocentrism (CET) with respect to acculturation to } \\
\text { global consumer culture (AGCC) }\end{array}$ \\
\hline Source:Aung
\end{tabular}

Source: Author's overview 
for preserving national or ethnic identity (Gonzales-Fuentes, 2019). The results of some of the observed studies also show that identity scores exceed the means of AGCC scores (Cleveland \& Laroche, 2007), and that identity and AGCC are negatively correlated (Sobol et al., 2018). In line with these results, consumer ethnocentrism and AGCC are found to be negatively related (Cleveland \& Laroche, 2007; Cleveland et al., 2015). The described results provide a conclusion that interplay between consumer ethnocentrism and identity initiates certain resistance to the globalization of consumer culture. On the other hand, it seems that exposure to the global culture does not necessarily initiate consumers' resistant responses. In the study of Canadian and Chilean consumers, consumer ethnocentrism appeared positively related to openness towards global culture as a dimension of overall AGCC (Cleveland et al., 2016). Authors argue that openness towards global culture does not necessarily bring erosion of national identity. On the contrary, in some cases these two forces seem to appear as complementary. Moreover, in the case of Japanese consumers, consumer ethnocentrism was found to be negatively related to identity and the lowest among consumers with the highest identity scores (Cleveland et al., 2015). It seems that, in the context of global acculturation processes, the relational matrix between identity and ethnocentrism is quite complexed and possibly interconnected with various variables (Gonzales-Fuentes, 2019).

\section{DISCUSSION}

Many aspects of the interplay between social identity and consumer ethnocentrism are under the influence of rapid social changes and social interpretation of those changes. In the framework of social identity theory, ethnocentric attachment to the ingroup initiates different forms of ingroup reactions, such as ingroup favouritism, cooperation and solidarity, especially in the face of shared social experience of common threats and challenges. Rapid social change in the globalized environment brings different threats to identity in the realistic and symbolic meanings. From the point of ingroup, intensive foreign competition can be interpreted as a common challenge or a threat to national welfare. Preferences towards domestic products, as symbols of ingroups, contribute to the preservation of group interest, and at the same time to maintaining positive social identity. Exchange of symbols and values of other cultures in the globalized environment can also be seen as a common challenge or threat to the ingroup. Global acculturation process, as a process of exchange of various aspects of different cultures, can be interpreted as a threat to the established ingroup identity. Empirical evidences about positive relationship between ethnocentrism and identity confirmed that consumer ethnocentrism represents a resistance force to the global acculturation processes. On the other hand, some studies have found different inconsistencies about relations between ethnocentrism and identity in that specific context. Social identity theory offers some important foundations for explaining these inconsistencies. Firstly, there are many factors which are important for increasing and decreasing the salience of group membership (Tajfel, 1974). Secondly, people have multiple identities derived from the various bases of social categorization and different identities can be activated at different times (Brewer, 1991). Thirdly, under the condition of global interdependence, security depends on the inclusion in stable, clearly differentiated social group (Brewer, 2007, p. 375). According to Brewer (2007), security motives, which include belonging and distinctiveness, underlie ingroup favouritism and vary as a function of intergroup relations and associated threats. Consequently, the relation among identity and consumer ethnocentrism, among other, includes perspective that the social experience of changes, as well as of threats and challenges, can be differently interpreted from the points of view of different identities and different social situations. 


\section{CONCLUSION}

The process of globalization brings about deep social changes, at the same time evoking a feeling of greater opportunities and of growing uncertainty (Yeganeh, 2011). Some authors noted earlier that globalization and identity are the most important forces shaping our time (Castells, 1997), with recent studies confirming that the rise of ethnocentric attitudes and increasing globalization are inter-connected processes (Bizumic, 2019). The overall theoretical and empirical analysis has confirmed consumer ethnocentrism as a relevant concept for consumers' responses to identity challenges in the globalized environment. From the point of view of understanding an interplay between social identity and consumer ethnocentrism, this analysis has emphasized the dynamic perspective of the social identity theory. This approach contributes to the explanation of consumer ethnocentrism in relation to processes of preserving and maintaining a social identity in the changing environment. The overall analysis contributes to a deeper theoretical understandings, as well as to the understanding of different consumer responses under the influence of mutual interaction of identity and consumer ethnocentrism. Theoretical part of the analysis offers a good starting points for further methodological approaches to examining the relationship between identity and consumer ethnocentrism. A synthesis of theoretical insights with an analysis of the empirical studies that deal with consumer ethnocentrism and identity provides a good foundation for explaining and predicting different consumers' responses and its marketing instrumentalization. Globalization is often seen as a simultaneous process of heterogenization and harmonization of consumer culture. The analysis of more recent empirical studies shows that the interplay between identity and consumer ethnocentrism to a certain extent represents reflections of those opposite processes. On the other hand, it is clear that globalization as a multifaceted process affects people's identities in different ways. The analysis of empirical studies confirmed the existence of different relational matrices between identity and ethnocentrism, leading to the conclusion that different dimensions of identity and ethnocentrism can be in different positions, depending on different factors and situations.

Identity and ethnocentrism are complex concepts rooted in different disciplines and researched from different perspectives. For that reasons this analysis focused on specific theoretical approaches and is linked to specific empirical studies that deal with both phenomena methodologically, in a similar manner. Although the accepted theoretical approach, as well as the analysis of selected consumers' studies, offers a solid basis for deeper understanding of the interplay between consumer ethnocentrism and identity, a multifaceted nature of this relationship requires additional theoretical perspectives. The main limitation of this analysis lies in the fact that observed theoretical backgrounds mostly consider classical propositions of the social identity theory and focuses primarily on the specific forms of identity. Therefore, further studies should apply additional or different theoretical perspectives, depending on the scope of analysis as well as on the context of research. 


\section{REFERENCES}

1. Balabanis, G., \& Diamantopoulos, A. (2004). Domestic country bias, country-of-origin effects and consumer ethnocentrism: a multidimensional unfolding approach. Journal of Marketing Science, 32(1), 80-95.

2. Bizumic, B. (2019). Effects of the dimensions of ethnocentrism on consumer ethnocentrism: An examination of multiple mediators. International Marketing Review, 36(5), 748-770.

3. Bizumic, B., \& Duckitt, J. (2012). What is and what is not ethnocentrism? Conceptual analysis and political implications. Political Psychology, 33(6), 887-909.

4. Brewer, M. B. (1991). The social self: On being the same and different at the same time. Personality and Social Psychology Bulletin, 17(5), 475-482.

5. Brewer, M. B. (1999). The psychology of prejudice: Ingroup love or outgroup hate? Journal of Social Issues, 55, 429-444.

6. Brewer, M. B. (2001). The many facets of social identity: Implications for political psychology. Political Psychology, 22(1), 115-125.

7. Brewer, M. B. (2007). The importance of being we: Human nature and intergroup relations. American Psychologist, 62, 728-738.

8. Castells, M. (1997). The information age: Economy, society and culture. The power of identity ( $2^{\text {nd }}$ vol.). Oxford: Blackwell Publishers.

9. Cleveland, M, Laroche, M., \& Papadopoulos, N. (2011). Ethnic identity's relationship to materialism and ethnocentrism: Contrasting consumers in developed and emerging economies. Journal of Global Academy of Marketing Science, 21(2), 55-71.

10. Cleveland, M., \& Laroche, M. (2007). Acculturation to the global consumer culture: Scale development and research paradigm. Journal of Business Research, 60(3), 249-259.

11. Cleveland, M., Laroche, M., \& Papadopoulos, N. (2009). Cosmopolitanism, consumer ethnocentrism and materialism: an eight-country study of antecedents and outcomes. Journal of International Marketing, 17(1), 116-146.

12. Cleveland, M., Laroche, M., \& Takahashi, I. (2015). The intersection of global consumer culture and national identity and the effect on Japanese consumer behavior. Journal of International Consumer Marketing, 27(5), 364-387.

13. Cleveland, M., Rojas-Méndez, J. I., Laroche, M., \& Papadopoulos, N. (2016). Identity, culture, dispositions and behavior: A cross-national examination of globalization and culture change. Journal of Business Research, 69(3), 1090-1102.

14. Cutura, M. (2012). The influence of ethnicity on consumers' purchase patterns in the context of Bosnia and Herzegovina. Ekonomska istrazivanja/Economic Research, Spec. Edition, 2, 83-102.

15. El Banna, A., Papadopoulos, N. Murphy, S. A, Rod, M., \& Rojas-Méndez, J. I. (2017). Ethnic identity, consumer ethnocentrism, and purchase intention among bi-cultural ethnic consumers: "Divided loyalties" or "Dual allegiance"? Journal of Business Research, 82 (Supplement C), 310-319.

16. Gonzales-Fuentes, M. (2019). Millennials' national and global identities as drivers of materialism and consumer ethnocentrism. The Journal of Social Psychology, 152(2), 170-189.

17. He, J., \& Wang, C. L. (2015). Cultural identity and consumer ethnocentrism impacts on preference and purchase of domestic versus import brands: An empirical study in China. Journal of Business Research, 68(6), 1225-1233.

18. Herche, J., \& Balasubramanian, S. (1994). Ethnicity and shopping behavior. Journal of Shopping Center Research, 1(1), 65-80.

19. Hershe, J. (1994). Ethnocentric tendencies, marketing strategy and import purchase behavior. International Marketing Review, 11(3), 4-16. 
20. Hogg, M. A., \& Abrams, D. (1988). Social identifications: A social psychology of intergroup relations and group processes. London: Routledge.

21. Hogg, M. A., Abrams, D., Otten, S., \& Hinkle, S. (2004). The social identity perspective: Intergroup relations, self-conception, and small groups. Small Group Research, 35(3), 246-276.

22. Kaynak, E., \& Kara, A. (2002). Consumer perception of foreign products: An analysis of product-country image and ethnocentrism. European Journal of Marketing, 36 (7/8), 928-950.

23. Keillor, B. D., \& Hult, G. T. M. (1999). A five-country study on national identity: Implications for international marketing research and practice. International Marketing Review, 16(1), 65-82.

24. Keillor, B. D., Hult, T. G., Erffmeyer, R. C., \& Babakus, E. (1996). NATID: The development and application of a national identity measure for use in international marketing. Journal of International Marketing, 4(2), 57-73.

25. Lantz, G., \& Loeb, S. (1996). Country-of-origin and ethnocentrism: An analysis of Canadian and American preferences using social identity theory. Advances in Consumer Research, 23, 374-388.

26. Pecotich, A., \& Rosenthal, M. J. (2001). Country of origin, quality, brand and consumer ethnocentrism. Journal of Global Marketing, 15(2), 31-60.

27. Phinney, J. S, Horenczyk, G., Leibkind, K., \& Vedder, P. (2001). Ethnic identity, immigration, and well-being: An interactional perspective. Journal of Social Issues, 57(3), 493-510.

28. Phinney, J. (1990). Ethnic identity in adolescents and adults: Review of research. Psychological Bulletin, 108, 499-514.

29. Sharma, S., Shimp, T. A., \& Shin, J. (1995). Consumer ethnocentrism: A test of antecedents and moderators. Journal of Academy of Marketing Science, 23(1), 26-37.

30. Shimp, T. A., \& Sharma, S. (1987). Consumer ethnocentrism: Construction and validation of CETSCALE. Journal of Marketing Research, 24, 280-289.

31. Sobol, K., Cleveland, M., \& Laroche, M. (2018). Globalization, national identity, biculturalism and consumer behavior: A longitudinal study of Dutch consumers. Journal of Business Research, 82(1), 340-353.

32. Stephan, W. G., \& Stephan, C. W. (2000). An integrated threat theory of prejudice. In S. Oskamp (Ed.), Reducing prejudice and discrimination (pp. 23-45). Mahwah, NJ: Erlbaum.

33. Stets, J. E., \& Burke, P. J. (2000). Identity theory and Social identity theory. Social Psychology Quarterly, 63(3), 224-237.

34. Sumner, G.W. (1906). Folkways. New York, NY: Ginn Custom Publishing.

35. Tajfel, H. (1974). Social identity and intergroup behavior. Social Science Information, 13(2), 65-93.

36. Tajfel, H. (1982). Social psychology of intergroup relations. Annual Review of Psychology, 33,1-39.

37. Tajfel, H., \& Turner, J. C. (2004). The Social Identity Theory of Intergroup Behavior. In J. T. Jost \& J. Sidanius (Eds.), Key readings in social psychology. Political psychology: Key readings (pp. 276-239). New York, NY: Psychology Press.

38. Tajfel, H., \&Turner, J. C. (1979). An integrative theory of intergroup conflict. In W. G. Austin \& S. Worchel (Eds.), The social psychology of intergroup relations (pp. 33-47). Monterey, CA: Brooks/ Cole.

39. Verlegh, P. W. J. (1999). Ingroups, outgroups and stereotyping: Consumer behavior and social identity theory. Advances in Consumer Research, 26, 162-164.

40. Verlegh, P. W. J. (2007). Home country bias in product evaluation: The complementary roles of economic and socio-psychological motives. Journal of International Business Studies, 38(3), 361 373.

41. Vida, I., \& Reardon, J. (2008). Domestic consumption: Rational, affective, or normative choice? Journal of Consumer Marketing, 25(1), 34-44. 
42. Vida, I., Dmitrovic, T., \& Obadia, C. (2008). The role of ethnic affiliation in consumer ethnocentrism. European Journal of Marketing, 42(3/4), 327-343.

43. Yeganeh, H. (2011). Liquid times: Living in an age of uncertainty. Society and Business Review, 6(3), 292-295.

44. Zarkada-Fraser, A., \& Fraser, C. (2002). Store patronage prediction for foreign-owned supermarkets. International Journal of Retail \& Distribution Management, 30(6), 282-99.

45. Zeugner-Roth, Zapkar, V., \& Diamantopoulos, A. (2015). Consumer ethnocentrism, national identity, and consumer cosmopolitism as a drivers of consumer behavior: A social identity theory perspective. Journal of International Marketing, 23(2), 25-54. 